\title{
SUSTAINABLE AGRICULTURE IN ORGANIC WHEAT (TRITICUM AESTIVUM L.) GROWING IN ARID REGION
}

\author{
N.S. AL-GHUMAIZ \\ Department of Plant Production and Protection, College of Agriculture and Veterinary Medicine, \\ Qassim University, Kingdom of Saudi Arabia.
}

\begin{abstract}
Qassim region is considered an urban, agricultural area in the Kingdom of Saudi Arabia. This region is characterized by dominant arid climate. Low fertility soil is considered a major challenge for the sustainable cultivation of wheat (Triticum aestivum L.). The objective of this study was to assess some agronomic characteristics of the wheat genotypes grown organically on low fertility soil. The experiments were conducted during the 2010 and 2011 growing seasons using eight bread wheat genotypes growing under conventional and organic farming systems at two different locations. Measurements of the following parameters were collected: chlorophyll content, flag leaf area $\left(\mathrm{cm}^{2}\right)$, and Harvest Index. Findings demonstrate a difference between the conventional and organic farming systems in terms of the parameters under study. Results showed that the greatest chlorophyll content was recorded in IC17 genotype (51.3 SPAD) Genotype Sids 12 had the highest FLA (28.0 and 26.3) under the conventional and organic farming systems, respectively. E-line and YR had the highest harvest index under the organic farming system in both the seasons. For sustainable food production in arid regions using the organic farming system, wheat genotypes YR and E-line could be the most suitable.

Keywords: arid region, conventional system, organic system, sustainable agriculture, wheat genotype.
\end{abstract}

\section{INTRODUCTION}

Wheat (Triticum aestivum L.) is globally important staple cereal because it constitutes the main source of protein and energy for people in most countries [1].

The use of chemical fertilizers in cereal production has increased worldwide [2] due to availability of inexpensive fertilizers [3]. The continued use of chemical fertilizers causes health and environmental hazards such as ground and surface water pollution by nitrate leaching [4]. So, reducing the amount of nitrogen fertilizers applied to a field without nitrogen deficiency will be the main challenge in field management.

Organic agriculture can be defined as a system that prohibits the use of synthetic fertilizers, chemical pesticides, and genetically modified organisms. As such, crop breeding and agronomic research is increasingly focusing on identifying parameters/traits, which, when adopted, can emulate the conditions and results of organic production.

Harvest Index (HI) can be used as a measure of reproductive efficiency [5]. In wheat, HI is an important parameter that can quantify the yield in terms of the total amount of biomass. Another such important parameter for wheat species is the flag leaf area. It has been found that flag leaf photosynthesis in wheat contributes to $\sim 30-50 \%$ of the assimilates during grain filling [6]. Maintaining chlorophyll content, however, is the major challenge of organic farming systems that utilize environment-friendly farming practices, to ensure high yield and excellent quality [7].

Several field trials have compared organic and conventional farming systems, and shown that there is a significant lower yield in the organic systems [8], [9]. In a long-term study in Sweden [10] comparing organic and conventional agriculture involving barley (Hordeum vulgare), wheat, and some other crops, it was shown that there is a disparity in productivity among the crops, as well as between the organic and conventional farming systems. 
Sustainable agriculture in urban areas with poor soil nutrients is a challenge. However, the promising results of our previous study, wherein we identified spring wheat genotype(s) suitable for cultivation under organic farming systems in arid regions [11], encouraged us to extend our study further to investigate the effects of selecting other agronomic characters including harvest Index, chlorophyll content $(\%)$ and flag leaf area $\left(\mathrm{cm}^{2}\right)$ on wheat productivity.

\section{MATERIALS AND METHODS}

Organic and conventional farming trials were conducted during the 2010 and 2011 growing seasons at two different locations (Farming systems). The conventional trial was established at Qassim University Agricultural Research Station, and involved the application of standard agricultural practices, including the use of chemical fertilizers as recommended by soil test results. The organic trial was established at the Research Center for Organic Agriculture, which is a certified organic farm near to the conventional trial $\left(26^{\circ} 18^{\prime} \mathrm{N}, 43^{\circ} 46^{\prime} \mathrm{E}\right.$, elevation of $648 \mathrm{~m}$ ). The organic trial was subjected to treatments adopted according to the organic system regulations set by the Ministry of Environment, Water and Agriculture of the Kingdom of Saudi Arabia (KSA).

Results of the analysis of soil chemical and physical properties of the two experimental stations are listed in Table 1. The maximum and minimum air temperatures during the 2010 and 2011 growing seasons (Jan to April) compared to the 27-year average are presented in Figs. 1 and 2, respectively.

Table 1: Results of analysis of the soil chemical and physical properties at the two experimental sites.

\begin{tabular}{llllllllll}
\hline & \multicolumn{3}{l}{} & \multicolumn{4}{c}{ Chemical analyses } & \multicolumn{4}{c}{ Physical properties } \\
\cline { 2 - 10 } Farming system & $\mathrm{K}(\mathrm{ppm})$ & $\mathrm{P}(\mathrm{ppm})$ & $\mathrm{N}(\mathrm{ppm})$ & $\mathrm{OM} \%$ & $\mathrm{pH}$ & Ec ds/m) & Clay \% & Silt \% & Sand \% \\
\hline Conventional & 34 & 33.1 & 15.7 & 0.14 & 8.1 & 5.3 & 0.4 & 4.2 & 94.9 \\
Organic & 36.5 & 22.1 & 52.5 & 1.4 & 7.9 & 1.9 & 0.9 & 4.5 & 94.5 \\
\hline
\end{tabular}

OM: Organic matter, Ec: Electrical conductivity.

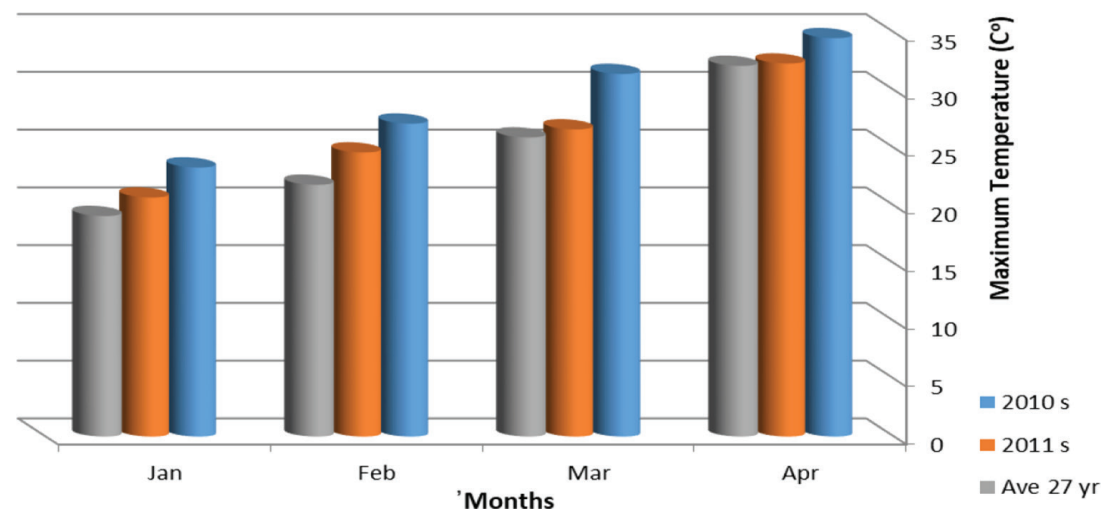

Figure 1: Monthly maximum air temperature during the two growing seasons compared to the 27-year average.

Source: The General Authority of Meteorology \& Environmental Protection-Saudi Arabia. http://www.pme.gov.sa 


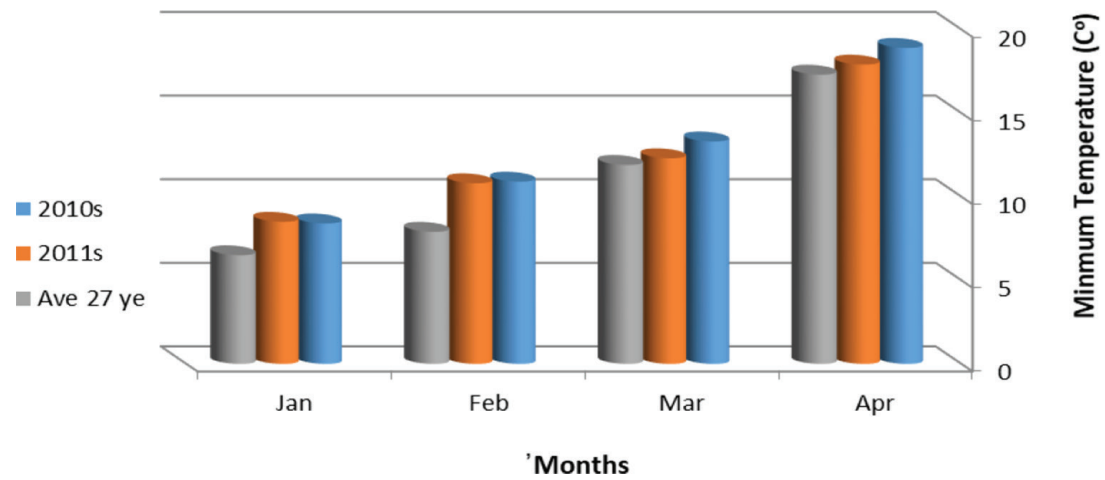

Figure 2: Monthly minimum air temperature during the two growing seasons compared to the 27- year average.

Source: The General Authority of Meteorology \& Environmental Protection-Saudi Arabia. http://www.pme.gov.sa

Eight bread wheat genotypes were used: Yocora Rojo (YR; the commercial genotype commonly grown in Saudi Arabia), Sama (the local genotype), the Australian genotypes P3 (AUS-030851) and P5 (AUS-030852), IC8 (Line-2-ICARDA-1 ${ }^{\text {st }}$ RDRN0607), IC17 (Line56 ICARDA- ${ }^{\text {st }}$ RDRN0607), and the Egyptian genotypes Early line (E.Line) and Sids 12.

The experiment was set up as a randomized complete block design (RCBD) with four replications using $3-\mathrm{m}^{2}$ plots $(1.5 \mathrm{~m} \times 2 \mathrm{~m})$. Seeding rates were 45 seeds per plot. The following parameters were measured: chlorophyll content (CHC), flag leaf area (FLA), and HI. After heading, 10 flag leaves were collected from each experimental unit and measured using a LI-3100 (LI-COR, Lincoln, Nebraska, USA) leaf area meter. Chlorophyll pigment was measured at the late booting stage on the top leaf of 10 plants in each experimental unit using a SPAD-501 Chlorophyll Meter (Konica Minolta, Co. Ltd., Japan).

Analysis of variance (ANOVA) was conducted on data of all the measured parameters, and the mean values for the eight wheat genotypes were compared using the least significant differences (LSD) test, with the level of significance set at $P<0.05$. Coefficient of variation (CV) was listed to measure the precision of the trial. Each location (Farming system) was analyzed as an independent experiment. The collected data for all variables were statistically analyzed using the MSTATC microcomputer program [12].

\section{RESULTS AND DISCUSSION}

There was a significant interaction between location (Farming system) and year in terms of HI and FLA. Similar interactions were also observed between location and genotype (Table 2). We attribute these interactions primarily to weather conditions varying between locations and between years (Figs 1 and 2), as well as to variations among the genotypes studied. No significant interaction was found between location and genotype in terms of chlorophyll content (Table 2).

\subsection{Chlorophyll content}

Chlorophyll content was affected by the farming system and genotype individually, although the effect of the interaction of these two factors was not significant (Table 2). Under the con- 
Table 2: Effect of farming systems and genotypes on some agronomic traits.

\begin{tabular}{llll}
\hline & Chlorophyll content (SPAD) & Flag leaf area $\left(\mathrm{cm}^{2}\right)$ & Harvest Index \\
\cline { 2 - 4 } Treatment & Location (Farming system) & & \\
\hline C-2010 & $51.9 \mathrm{a}$ & $10.3 \mathrm{c}$ & $0.33 \mathrm{c}$ \\
Or-2010 & $49.8 \mathrm{ab}$ & $9.8 \mathrm{c}$ & $0.37 \mathrm{~b}$ \\
C- 2011 & $49.5 \mathrm{~b}$ & $20.8 \mathrm{a}$ & $0.40 \mathrm{a}$ \\
Or-2011 & $49.4 \mathrm{~b}$ & $20.8 \mathrm{a}$ & $0.37 \mathrm{~b}$ \\
Sig & $* *$ & $* *$ & $* *$ \\
\hline Genotype & & & \\
\hline Y R & $49.5 \mathrm{~b}$ & $14.0 \mathrm{c}$ & $0.45 \mathrm{a}$ \\
Local & $45.8 \mathrm{~d}$ & $18.8 \mathrm{a}$ & $0.28 \mathrm{~d}$ \\
P3 & $46.9 \mathrm{~cd}$ & $14.2 \mathrm{c}$ & $0.37 \mathrm{c}$ \\
P 5 & $47.1 \mathrm{~cd}$ & $15.7 \mathrm{~b}$ & $0.36 \mathrm{c}$ \\
IC 8 & $47.3 \mathrm{~cd}$ & $10.6 \mathrm{e}$ & $0.38 \mathrm{bc}$ \\
IC 17 & $51.3 \mathrm{a}$ & $16.1 \mathrm{~b}$ & $0.38 \mathrm{bc}$ \\
E. Line & $48.1 \mathrm{bc}$ & $12.1 \mathrm{~d}$ & $0.45 \mathrm{a}$ \\
Sids 12 & $48.9 \mathrm{~b}$ & $18.9 \mathrm{a}$ & $0.40 \mathrm{~b}$ \\
Sig & $* *$ & $* *$ & $* *$ \\
L×G & Ns & $* *$ & $* *$ \\
\hline C-2010: & & & $2010,0 \mathrm{r}$ \\
\hline
\end{tabular}

C-2010: Conventional 2010, C-2011: Conventional 2011, Or 2010: Organic 2010, Or 2011: Organic 2011.

ns and $* *=$ not significant at 0.05 and significant at 0.01 level of probability, respectively Means in column within each factor designated by the same latter are not statistically different at 0.05 level of probability using the (LSD).

ventional system, the chlorophyll content was the highest during 2010 season (51.9 SPAD). Genotype IC17 demonstrated the greatest chlorophyll content (51.3 SPAD). YR and the Egyptian genotypes (E-line and Sids 12) had higher chlorophyll content comparable to those in the local, and Australian genotypes (P3 and P5).

\subsection{Flag leaf Area $\left(\mathrm{cm}^{2}\right)$}

The area of flag leaf was not affected by the farming system. Only one genotype (P3) had significantly different FLA when grown under the two farming systems during the 2010 growing season. Genotype Sids 12 had the highest FLA (28.0 and $\left.26.3 \mathrm{~cm}^{2}\right)$ under the conventional and organic farming systems, respectively, in 2011. FLA varied significantly between the two growing seasons $(P<0.05)$, with the 2011 season recording the highest FLA in both the farming systems. (Table 3 ).

\subsection{Harvest index}

There was no significant difference between the conventional and organic farming systems, in terms of HI, with the exception of IC17, which showed a highly significant difference 
Table 3: Effect of interaction between the two farming systems and genotypes on flag leaf area $\left(\mathrm{cm}^{2}\right)$.

\begin{tabular}{|c|c|c|c|c|}
\hline \multirow[b]{2}{*}{ Genotype } & \multicolumn{4}{|c|}{ Flag leaf area $\left(\mathrm{cm}^{2}\right)$} \\
\hline & C-2010 & Or-2010 & C- 2011 & Or-2011 \\
\hline Y R & 10.9 & 8.7 & 19.1 & 18.3 \\
\hline Local & 12.9 & 13.4 & 25.4 & 27.5 \\
\hline P3 & 10.7 & 7.0 & 21.0 & 21.1 \\
\hline P 5 & 10.3 & 10.1 & 22.1 & 23.4 \\
\hline IC 8 & 7.1 & 8.5 & 13.0 & 15.2 \\
\hline IC 17 & 10.3 & 12.8 & 21.6 & 20.2 \\
\hline E. Line & 8.8 & 7.0 & 16.3 & 14.4 \\
\hline Sids 12 & 11.1 & 11.1 & 28.0 & 26.3 \\
\hline LSD & 3.4 & & & \\
\hline
\end{tabular}

C: conventional, Or: Organic.

Table 4: Effect of interaction between the two farming systems and genotypes on HI.

\begin{tabular}{lllll}
\hline & \multicolumn{3}{l}{ Harvest Index } & \\
\cline { 2 - 5 } Genotype & C-2010 & Or-2010 & C- 2011 & Or-2011 \\
\hline Y R & 0.41 & 0.46 & 0.46 & 0.45 \\
Local & 0.24 & 0.26 & 0.28 & 0.24 \\
P3 & 0.31 & 0.34 & 0.39 & 0.35 \\
P5 & 0.30 & 0.34 & 0.37 & 0.32 \\
IC 8 & 0.30 & 0.34 & 0.41 & 0.37 \\
IC 17 & 0.30 & 0.40 & 0.39 & 0.34 \\
E. Line & 0.39 & 0.43 & 0.47 & 0.48 \\
Sids 12 & 0.36 & 0.38 & 0.41 & 0.39 \\
LSD & 0.05 & & & \\
\hline
\end{tabular}

C: conventional, Or: Organic.

$(P<0.05)$ between the two systems. Interestingly, E-line and YR had the highest HI under the organic farming system in both the seasons. Growing such genotypes can help for sustainable food production in urban regions.

There was a significant difference $(P<0.05)$ between the 2010 and 2011 growing seasons in terms of the HI only under the conventional farming system (Table 4).

\section{CONCLUSIONS}

Organic farming systems can be adopted for ensuring a clean environment and sustainable crop production. In wheat cultivation, selection of some specific parameters such as chlorophyll content and HI, can be important to ensure the success of organic farming. For sustainable production in arid regions using the organic farming system, wheat genotypes YR and E-line could be the most suitable. 


\section{ACKNOWLEDGEMENTS}

The author acknowledges the Deanship of Scientific Research at Qassim University for funding this project. I gratefully thanks Dr. Mohammed Motawei for reviewing this paper and Dr. Abdel-Salam Menshawy for his assistance with the statistical analyses. I would like to thank Editage (www.editage.com) for English language editing.

\section{REFERENCES}

[1] Bos, C., Juillet, B., Fouillet, H., Turlan, L., Dare, S., Luengo, C., N`tounda, R., Benamouzig, R., Gausseres, N., Tome, D. \& Gaudichon, C., Postprandial metabolic utilization of wheat protein in humans. The American Journal of Clinical Nutrition, 81(1), pp. 87-94, 2005. https://doi.org/10.1093/ajcn/81.1.87

[2] Abril, A., Baleani, D., Casado-Murillo, N. \& Noe, L., Effect of wheat crop fertilization on nitrogen dynamics and balance in the Humid Pampas, Argentina. Agriculture, Ecosystems \& Environment, 119(1-2), pp. 171-176, 2007. https://doi.org/10.1016/j. agee.2006.07.005

[3] Graham, P.H. \& Vance, C.P., Nitrogen fixation in perspective: an overview of research and extension needs. Field Crops Research 65(2-3), pp. 93-106, 2000. https://doi. org/10.1016/s0378-4290(99)00080-5

[4] Pimentel, D., Green revolution and chemical hazards. Science of the Total Environment, 188(supplement), pp. S86-S98, 1996. https://doi.org/10.1016/0048-9697(96)05280-1

[5] Murray, U., Jeff, B. \& Matthew, F., Variability in harvest index of grain crops and potential significance for carbon accounting: Examples from Australian agriculture. Advances in Agronomy, ed. D.L. Sparks, pp 173-219, Elsevier, 2010.

[6] Sylvester, B.R., Stokes, D.T. \& Scott, R.K., A physiological analysis of the diminishing responses of winter wheat to applied nitrogen, 1. Theory. Aspects of Applied Biology, pp. 277-287, 1990.

[7] Tilman, D., Cassman, K.G., Matson, P.A., Naylor, R. \& Polasky, S., Agriculture sustainability and intensive production practices. Nature, 418(6898), pp. 671-677, 2002. https://doi.org/10.1038/nature01014

[8] Ryan, M.H., Derrick, J.W. \& Dann, P.R., Grain mineral concentrations and yield of wheat grown under organic and conventional management. Journal of the Science of Food and Agriculture, 84(3), pp. 207-216, 2004. https://doi.org/10.1002/jsfa.1634

[9] Stanhill, G., The comparative productivity of organic agriculture. Agriculture. Ecosystems \& Environment, 30(1-2), pp. 1-26, 1990. https://doi.org/10.1016/0167-8809(90)90179-h

[10] Kirchmann, H., Bergström, L., Kätterer, T. \& Gesslein, S., Comparison of long-term organic and conventional crop-livestock systems on a previously nutrient-depleted soil in Sweden. Agronomy Journal, 99(4), pp. 960-972, 2007. https://doi.org/10.2134/ agronj2006.0061

[11] Al-Ghumaiz, N.S., Yield performance quality of eight wheat genotypes under organic and conventional farming systems in Saudi Arabia. Agriculture and Food, 2, pp. 20-24, 2014. [Online] Available: http://www.scientific-publications.net/en/article/1000002/

[12] MSTATC. A microcomputer program for the design. Management, and Analysis of Agronomic Research Experiments. Michigan State University East Lansing, MI, USA. 1990. 